\title{
HUBUNGAN CITRA TUBUH DENGAN STATUS OBESITAS, AKTIVITAS FISIK DAN ASUPAN ENERGI REMAJA SLTP DI KOTA YOGYAKARTA DAN KABUPATEN BANTUL
}

\author{
Novriani Tarigan', Hamam Hadi², Madarina Julia ${ }^{3}$
}

\begin{abstract}
Background: The prevalence of obesity in adolescence, both in industrial and in developing countries, is increasing. This might be due to the fact that globalization has affected the lifestyle and the eating pattern of the adolescents.. Apart from related to higher risk of cardiovascular morbidity and mortality, obesity in adolescents might be also related to dissatisfaction of body image.

Objective: To asses the association between obesity and body image, and between body image and energy intake and physical activities of junior high school adolescents in the District of Yogyakarta and Bantul.

Method: This is a cross-sectional study. Subjects were 96 pairs of 12-15 years old obese and non-obese adolescents, identified in the obesity screening programs in junior high schools in Yogyakarta and Bantul. Subjects were asked to complete 34 questions on body shape image. Energy intake and physical activity data were obtained by food-and physical-activity-frequency questionnaires.

Results: Obese adolescents had higher odds to be dissatisfied to their body images compared to their non-obese peers, i.e. Mantel-Haenszel Odds Ratio (95\% Cl) of 14.6(6.234.4). Obese female adolescents had higher odds to be dissatisfied than their male counterparts, OR $(95 \% \mathrm{Cl})$ of 19.5(2.4-15.9) in female and OR $(95 \% \mathrm{Cl})$ of $13.4(5.3-33.8)$ in male adolescents. There were no significant associations between dissatisfaction status with energy intake and time spent on light physical activities. Dissatisfied adolescents tended to spend less time on hard physical activities compared to their satisfied peers.

Conclusion: Obese adolescents were more likely to be dissatisfied with their body images compared to their non-obese peers, but the dissatisfaction did not lead to less energy intake and more time spent on harder physical activities.
\end{abstract}

Key words: adolescent obesity, body image, energy intake, physical activities

\section{PENDAHULUAN}

Prevalensi obesitas di banyak negara, baik di negara industri dan negara berkembang terus meningkat dari tahun ke tahun (1). Misalnya, prevalensi obesitas pada anak usia 6-17 tahun di Amerika Serikat dalam tiga dekade terakhir meningkat dari 7,6-10,8\% menjadi 13-14\% (2). Dari hasil penelitian di Malaysia diketahui prevalensi kegemukan adalah 23,9\% laki-laki dan $19,6 \%$ perempuan (3).
Di Indonesia, prevalensi obesitas pada balita menurut SUSENAS menunjukkan peningkatan baik di perkotaan maupun pedesaan. Di perkotaan pada tahun 1989 didapatkan prevalensi 4,6\% laki-laki dan 5,9\% perempuan. Pada tahun 1995 prevalensi obesitas di 27 propinsi adalah 4,6\%. Di DKI Jakarta, prevalensi obesitas meningkat seiring dengan bertambahnya umur. Pada umur 6-12 tahun ditemukan obesitas sekitar 4\%, pada anak remaja 12-18 tahun ditemukan $6,2 \%$, dan pada umur $17-18$ tahun $11,4 \%$. Kasus obesitas pada remaja lebih banyak ditemukan pada perempuan $10,2 \%$ dibanding laki-laki 3,1\% (4). Pada remaja SLTP di Surabaya prevalensi obesitas sebesar 8,5\% (5). Di Kota Yogyakarta dan Kabupaten Bantul, pada tahun 2003 didapatkan prevalensi obesitas masing-masing $7,8 \%$ dan $2,0 \%(6)$.

Bersama dengan berbagai persoalan medis yang berhubungan dengan kelebihan berat badan, ketidakpuasan citra tubuh (body image dissatisfaction-BID) telah dikenali sebagai konsekuensi psikosial paling konsisten dari obesitas. Dengan didefinisikannya BID sebagai ketidaksukaan dan ejekan atas tubuh maka BID menjadi semakin sering dijumpai di kalangan penderita obes dibandingkan dengan bukan obes, dan lebih banyak terjadi pada perempuan obes dibandingkan dengan laki-laki obes (7).

Selama 2 dekade terakhir hampir semua menyatakan bahwa laki-laki dan perempuan sedang meningkatkan ketidakpuasaannya terhadap bentuk tubuhnya. Psychology Today tahun 1997 melakukan survei citra tubuh yang melibatkan 4000 laki-laki dan perempuan. Lima puluh enam persen perempuan mengungkapkan bahwa mereka tidak puas terhadap penampilan keseluruhan mereka dan $89 \%$ perempuan bermaksud menurunkan berat badannya. Lima puluh empat persen gadis-gadis berusia 13-19 tahun ternyata tidak puas, dan $41 \%$ anak laki-laki pada usia yang sama melaporkan ketidakpuasan secara umum. Angka ini ternyata lebih banyak dibandingkan dengan survei sebelumnya yang dilakukan oleh majalah yang sama pada tahun 1972 dan 1985. Mengapakah makin banyak orang tidak puas pada bentuk tubuhnya? (8).

\footnotetext{
Jurusan Gizi Politeknik Kesehatan Medan

Magister Gizi dan Kesehatan UGM Yogyakarta

Bagian Anak RSUP Dr. Sardjito/Fakultas Kedokteran UGM Yogyakarta
} 
Nichter (9) dalam bukunya Fat Talk menyatakan bahwa citra tubuh selalu dihubungkan dengan eating disorders (anorexia nervosa dan bulimia nervosa). Padahal sebenarnya hanya $1-3 \%$ remaja putri yang mengalami eating disorders, lalu bagaimana dengan $97 \%$ yang lain. Jika memang berdiet, mengapa terus menerus dilaporkan peningkatan prevalensi obesitas.

\section{BAHAN DAN METODE}

Jenis penelitian ini adalah penelitian observasional dengan menggunakan rancangan cross sectional. Subjek penelitian diambil dari populasi remaja SLTP berusia antara 12-15 tahun di Kota Yogyakarta dan Kabupaten Bantul yang diidentifikasi dari survei Penelitian Bersama Mengenai Obesitas pada Remaja SLTP di Kota Yogyakarta dan Kabupaten Bantul tahun 2003 (6). Dari survei tersebut diperoleh data 191 remaja obes dan 182 remaja tidak obes. Dengan mensetarakan terhadap jenis kelamin, usia, dan asal sekolah, dari data tersebut diambil 96 pasang remaja obes dan tidak obes.

Penelitian ini dilaksanakan pada bulan Agustus sampai dengan Oktober 2004. Data identitas subjek, sosial ekonomi, aktivitas fisik, dan asupan energi diperoleh dari data sebelumnya (6). Data identitas subjek diperoleh dengan cara memberikan kuesioner kepada subjek penelitian. Pendidikan orangtua adalah jenjang formal terakhir yang pernah ditempuh oleh ayah, ibu. Data ini dikelompokkan menjadi 3, yaitu: dasar (tidak sekolah, tidak tamat SD, tidak tamat SLTP), menengah (tamat SLTP, tidak tamat SLTA, tamat SLTA), dan tinggi (tidak tamat akademi/PT, tamat akademi/PT). Data sosial ekonomi dikumpulkan dengan metode wawancara kepada orang tua subjek penelitian dengan alat bantu kuesioner. Data ini dikelompokkan menjadi 2 dengan menggunakan cut off mean pendapatan keluarga dengan pembulatan ke desimal terdekat.

Data aktivitas fisik, dikumpulkan dengan wawancara langsung dengan alat bantu kuesioner aktivitas fisik. Aktivitas fisik yang diukur adalah kegiatan yang dilakukan secara teratur dalam 3 bulan terakhir. Kuesioner tersebut disusun berdasarkan International Physical Activity Questionnaire (IPAQ) dengan modifikasi untuk anak SLTP. Penyusunan kuesioner dilakukan dengan mengadakan diskusi kelompok terarah dan wawancara mendalam serta diuji cobakan terlebih dahulu. Aktivitas fisik dikelompokkan menjadi: 1) aktivitas ringan, yaitu aktivitas yang tidak menimbulkan perubahan nafas, termasuk di antaranya adalah aktivitas berjalan dari satu tempat ke tempat lain, duduk setiap hari sembari bekerja, di rumah, di waktu senggang, duduk lama di bangku, mengunjungi teman, membaca, berbaring serta menonton TV, dihitung dalam jam per hari; 2) aktivitas sedang, yaitu aktivitas yang menimbulkan perubahan nafas lebih berat daripada normal, termasuk di antaranya adalah membawa beban ringan, bersepeda dengan kecepatan teratur, bermain tenis ganda dan sebagainya, dihitung dalam jam per hari; 3 ) aktivitas berat adalah aktivitas yang menimbulkan perubahan nafas yang sangat berat daripada normal, termasuk di antaranya adalah mengangkat beban, menggali, aerobik, bersepeda cepat, dihitung dalam jam per hari; 4) aktivitas tidur adalah seluruh waktu yang digunakan untuk tidur siang dan malam, dihitung dalam jam per hari.

Data asupan energi diambil dengan wawancara dengan menggunakan kuesioner penelitian Food Frequency Questionnaire (FFQ), kemudian asupan energi dihitung dengan program nutrisurvey. Asupan energi adalah persentase jumlah energi yang disumbangkan untuk kebutuhan tubuh remaja $(6,10)$.

Subjek penelitian baik yang obes maupun yang tidak obes diukur kembali tinggi badan dan berat badannya untuk memastikan bahwa tidak ada perubahan status obesitas. Bila terjadi perubahan, remaja tersebut berubah dari obes menjadi tidak obes dan sebaliknya tidak obes menjadi obes, maka remaja tersebut tidak dimasukkan sebagai subjek penelitian. Penggantinya diambil sesuai ketentuan. Tinggi badan diukur dengan menggunakan microtoise dengan ketelitian 0,1 cm, sedangkan berat badan ditimbang menggunakan timbangan injak dengan kapasitas 150 $\mathrm{kg}$ dan tingkat ketelitian $0,1 \mathrm{~kg}$. Selanjutnya hasil pengukuran yang didapat dibandingkan baku NCHS/ CDC untuk laki-laki dan perempuan usia 2-20 tahun dengan indikator yang digunakan adalah Indeks Massa Tubuh (IMT) menurut umur. Dinyatakan obes bila IMT subjek penelitian berada pada atau di atas kurva persentil 95 dari Baku NCHS/CDC. Tidak obes bila berada di bawah kurva persentil 95 dari Baku NCHS/CDC (11).

Data citra tubuh remaja dikumpulkan dengan cara memberikan kuesioner Body Shape Questionnaire (BSQ) yang terdiri dari 34 pertanyaan dengan menggunakan skala rentang 1 (tidak pernah) sampai rentang 6 (selalu) $(12,13)$. Kuesioner tersebut diuji coba di dua SMP Negeri dengan jumlah subjek 42 orang. Dilakukan uji korelasi antara skor setiap nomor pertanyaan dengan total seluruh skor BSQ. Skor dari lima pertanyaan ternyata tidak berkorelasi dengan skor total, sehingga pertanyaan tersebut diperbaiki susunan kalimatnya supaya lebih jelas.

Kuesioner yang sudah diuji coba tersebut diberikan pada subjek penelitian dan subjek mengisinya sesuai 
dengan petunjuk. Data tersebut kemudian dikelompokkan menjadi 2 dengan menggunakan cut off mean skor $B S Q$ remaja yang tidak obes, sehingga diperoleh kelompok puas dengan skor $B S Q<62$, sedangkan kelompok tidak puas dengan skor $B S Q \geq 62$. Pada analisis dilakukan penstratifikasian status obesitas dan citra tubuh menjadi 4 kategori, yaitu: 1) tidak obes puas, 2) tidak obes tidak puas, 3 ) obes puas, 4) obes tidak puas (Tabel 3).

Pengumpulan data dilakukan oleh peneliti dibantu 2 orang mahasiswa S1 Gizi yang sudah diseleksi sebelum pelaksanaaan penelitian. Pada data yang telah terkumpul, dilakukan coding dan cleaning kemudian dilakukan entri dan analisis data dengan menggunakan komputer. Analisis statistik dilakukan pada derajat kemaknaan $95 \%$ dan $p<0,05$. Analisis statistik yang dilakukan adalah analisis univariat, dengan menghitung distribusi frekuensi dan proporsi karakteristik subjek penelitian serta analisis bivariat menggunakan uji t dan uji kai kuadrat untuk membandingkan karakteristik subjek penelitian. Selain itu dilakukan analisis stratifikasi untuk mengetahui hubungan status ketidakpuasan citra tubuh menurut jenis kelamin dengan status obesitas.

\section{HASIL DAN BAHASAN}

Subjek penelitian ini terdiri dari 59 pasang remaja obes dan tidak obes laki-laki serta 37 pasang remaja obes dan tidak obes perempuan. Ada 57 pasang remaja obes dan tidak obes yang berasal dari SLTP di Kota Yogyakarta dan 39 pasang remaja obes dan tidak obes dari SLTP di Kabupaten Bantul.

Penelitian ini menunjukkan tidak ada perbedaan bermakna karakteristik pendapatan keluarga, pendidikan ayah, pendidikan ibu, pekerjaan ayah, dan pekerjaan ibu subjek penelitian berdasarkan status obesitas (Tabel 1). Tidak ada pula perbedaan karakteristik umur, pendapatan keluarga, pendidikan ayah, pendidikan ibu, pekerjaan ayah dan pekerjaan ibu subjek penelitian berdasarkan citra tubuh atau ketidakpuasan terhadap tubuhnya (Tabel 2). Hal ini sejalan dengan penelitian Nichter (9) yang menyatakan tidak ada perbedaan yang bermakna pada suku, tingkat pendidikan ayah dan ibu dalam hal citra tubuh. Penelitian Snooks dan Sharon (14) juga menyatakan tidak ada perbedaan dalam pengelompokan etnis pada citra tubuh, tetapi ada hubungan terbalik yang kuat antara status sosial ekonomi dengan berat badan dan citra tubuh di antara perempuan di negara maju. Perempuan yang status

TABEL 1. Distribusi karakteristik subjek

\begin{tabular}{|c|c|c|c|c|c|c|}
\hline \multirow{2}{*}{ Buithe } & \multicolumn{2}{|c|}{ Ahes } & \multicolumn{2}{|c|}{ Tuth ofut } & \multirow{2}{*}{$i^{4}$} & \multirow{2}{*}{ I } \\
\hline & if & $\mathrm{s}$ & in & te & & \\
\hline \multicolumn{7}{|l|}{ Fio } \\
\hline hw & tF & dit. & I & $1+$ & unt & $0+3$ \\
\hline Hoi dow & 15 & 104 & 67 & $m ;$ & & \\
\hline Inthi & $\mathrm{H}$ & 1010 & 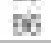 & 1017 & & \\
\hline \multicolumn{7}{|c|}{ Herispotan have } \\
\hline +2uausu & 53 & MI & $\omega$ & 84 & ting & 47 \\
\hline 25000 & 45 & 44 & M & 24 & & \\
\hline mah & W & pai & (n) & ing. & & \\
\hline \multicolumn{7}{|l|}{ Arethenthe } \\
\hline gyt & 15 & $15=$ & H & 213 & 38 & IN \\
\hline Shmond & $\pi$ & 741 & 5 & 100 & & \\
\hline thy & 3 & 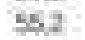 & 40 & 110 & & \\
\hline Intul. & A. & 300 & 6 & wile & & \\
\hline \multicolumn{7}{|l|}{ Photriba bi } \\
\hline Dint & 12 & $\mid T_{i} P$ & $\mathrm{~s}$ & AI & $1 W$ & ny \\
\hline Mrampit & y: & dit & 8 & 44 & & \\
\hline Thy & 41 & 47 & is & $3 \bar{A}$ & & \\
\hline iernati & it & 1000 & H & ine & & \\
\hline \multicolumn{7}{|l|}{ Rolindin } \\
\hline Buhnit. & 5 & He: & Et & sis & $3 x$ & nas \\
\hline Armpapdi & 20 & Ni & IT & $\mathrm{WiT}$ & & \\
\hline What 4 & 27 & 4 & 4 & II & & \\
\hline Mnh. & A: & $\mathrm{mo}$ & $\omega$ & mo & & \\
\hline \multicolumn{7}{|l|}{ Bular it } \\
\hline InEmutat & 65 & tas & EE: & 87 & 1, 19. & $\mathrm{H}+\mathrm{H}$ \\
\hline 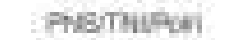 & it: & 74 & 17 & $\mathrm{Mr}$ & & \\
\hline Wnsint & 12 & 125 & 14 & $14 \mathrm{~A}$ & & \\
\hline darah: & $m$ & 91 & w & me & & \\
\hline
\end{tabular}


TABEL 2. Distribusi karakteristik individu menurut status ketidakpuasan citra tubuh

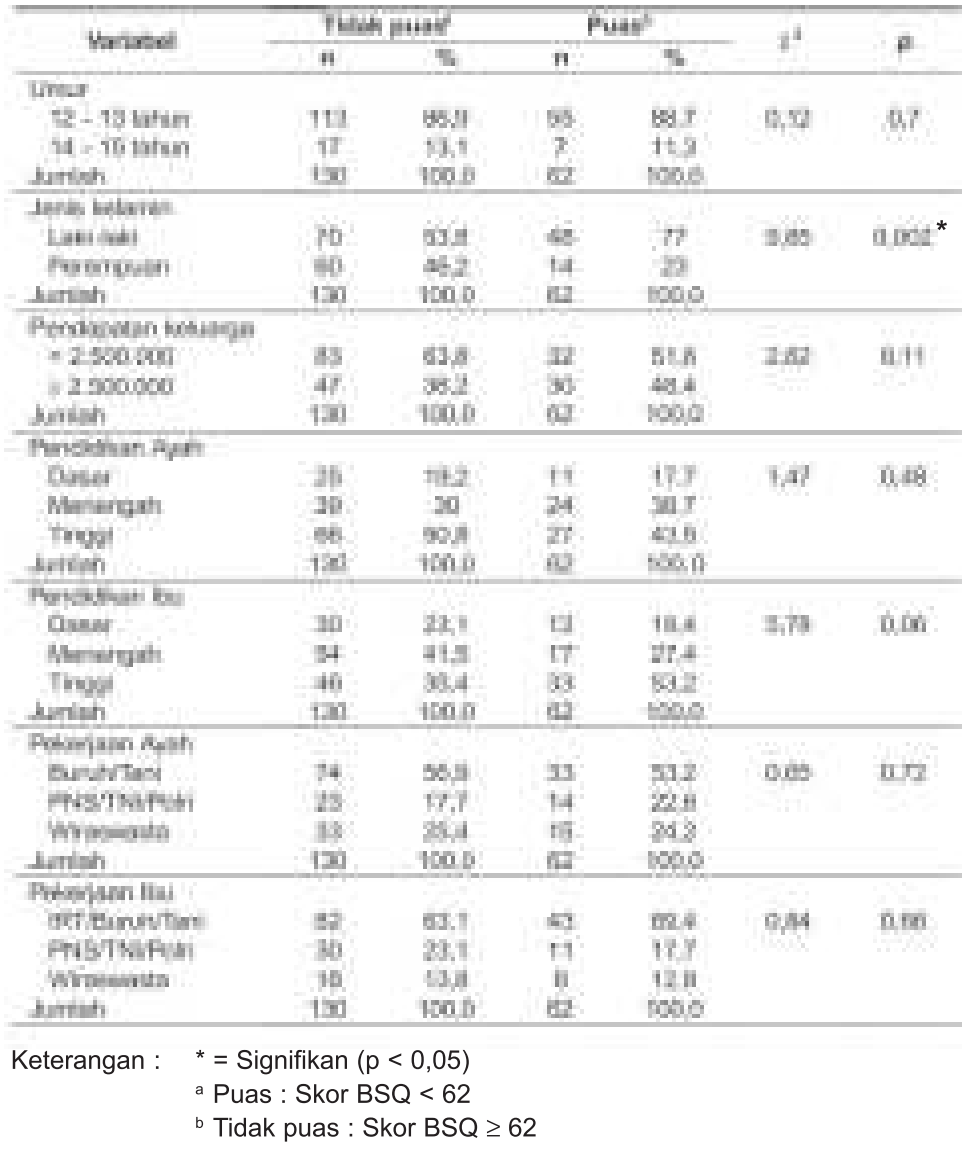

sosial ekonominya tinggi cenderung lebih langsing dibandingkan yang status sosial ekonominya lebih rendah. Matz et al (7) juga menemukan tidak ada hubungan citra tubuh dengan suku dan sosial ekonomi. Yang agak bertentangan adalah Metcalf et al (15) yang menemukan dalam penelitian tentang persepsi terhadap bentuk dan ukuran tubuh di beberapa negara berkembang: persepsi seseorang yang mengalami obesitas terhadap bentuk dan ukuran tubuhnya berbeda-beda dan dipengaruhi oleh etnik/ras, sosial ekonomi, kebudayaan dan pendidikan.

Dari penelitian ini diketahui mean (SD) skor BSQ remaja obes sebesar 102,26 $(33,55)$ dan remaja tidak obes $61,74(15,19)(p<0,001)$, artinya ada perbedaan yang bermakna skor BSQ remaja obes dan tidak obes. Tidak jauh berbeda dengan penelitian ini Matz et al (7) memperoleh rata-rata skor BSQ sebesar $98,81(27,29)$ pada perempuan overweight.

Mean (SD) skor citra tubuh berdasarkan status obesitas dan status ketidakpuasan citra tubuh pada kelompok tidak obes puas sebesar $51,2(7,1)$. Kelompok ini dipakai sebagai referens. Perbedaan skor citra tubuh kelompok tidak obes tidak puas terhadap referens sebesar 23,5. Sedangkan kelompok obes tidak puas mempunyai skor yang jauh lebih tinggi, dengan perbedaan skor sebesar 55,9. Pada kelompok obes puas, perbedaan skor dengan referens hanya sebesar 4,8 (Tabel 3).

Pada penelitian ini $91 \%$ remaja obes menyatakan tidak puas dengan ukuran tubuhnya. Hasil uji kai kuadrat menunjukkan adanya hubungan yang bermakna antara status obesitas dengan status ketidakpuasan citra tubuh. Remaja obes mempunyai kecenderungan untuk tidak puas terhadap bentuk tubuhnya 11,9 kali lebih besar daripada remaja tidak obes.

Selama dua dekade terakhir hampir semua menyatakan bahwa laki-laki dan perempuan sedang meningkat ketidakpuasan terhadap bentuk tubuhnya. Body image dissatisfaction (BID) atau ketidakpuasan terhadap bentuk tubuh lebih sering dijumpai di kalangan penderita obes dibandingkan dengan bukan obes dan lebih banyak terjadi pada perempuan obes dibandingkan dengan laki-laki obes (7). Beberapa penelitian menyatakan bahwa ketidakpuasan citra tubuh berbeda antara laki-laki dan perempuan. Hal ini juga ditemukan pada penelitian ini. 
TABEL 3. Mean nilai citra tubuh berdasarkan status obesitas dan status ketidakpuasan citra tubuh menurut skor BSQ

\begin{tabular}{|c|c|c|c|c|}
\hline Kelompok & $\begin{array}{c}\text { Mean (SD) } \\
\text { Citra Tubuh }\end{array}$ & $\begin{array}{c}\text { Mean } \\
\text { Difference }\end{array}$ & $95 \% \mathrm{Cl}$ & $p$ \\
\hline Tidak cbes puas" & $51,2(7,1)$ & Ofreferens) & - & - \\
\hline Tidak obes tidak puas " & $74,7(12,1)$ & 23,5 & $19,6-27,5$ & $<0,001^{*}$ \\
\hline Obes puas & $55,2(3,9)$ & 4.8 & $-8,9-0,8$ & 0,10 \\
\hline Obes tidak puas & $107,1(31,4)$ & 55,9 & $47,2-64,6$ & $<0,001^{*}$ \\
\hline $\begin{array}{ll}\text { Keterangan: } & { }^{*}=\text { Signifik } \\
& { }^{\text {a }} \text { Puas }=\text { S } \\
& { }^{b} \text { Tidak pua }\end{array}$ & $\begin{array}{l}<0,05) \\
S Q<62 \\
\text { kor } B S Q \geq 62\end{array}$ & & & \\
\hline
\end{tabular}

Ada perbedaan status ketidakpuasan citra tubuh laki-laki dan perempuan. Remaja laki-laki obes mempunyai peluang untuk tidak puas sebesar 13,4 kali. Ini masih lebih rendah dibanding remaja perempuan yang mempunyai peluang untuk tidak puas sebesar 19,5 kali. Ada perbedaan antara OR yang dihitung secara kasar, $(O R=11,9)$ dan OR Mantel Haenszel $\left(\mathrm{OR}_{\mathrm{MH}}=14,6\right)$, berarti pada hal ini ada interaksi statistik dan efek modifier untuk jenis kelamin (Tabel 4). dengan rasa percaya diri, ketidakpuasan citra tubuh bisa diatur oleh rasa percaya diri. Hal ini mungkin dapat menerangkan mengapa remaja laki-laki obes lebih puas daripada remaja perempuan obes.

Pada penelitian ini tidak ada hubungan ketidakpuasan citra tubuh dengan aktivitas ringan, aktivitas sedang dan aktivitas tidur, tetapi ada hubungan yang bermakna antara status ketidakpuasan citra tubuh dengan aktivitas berat. Remaja yang tidak puas

TABEL 4. Hubungan status obesitas menurut jenis kelamin dengan status ketidakpuasan citra tubuh

\begin{tabular}{|c|c|c|c|c|c|c|}
\hline \multirow{2}{*}{\multicolumn{2}{|c|}{ Jenis kelamin }} & \multicolumn{2}{|c|}{$\begin{array}{l}\text { Status ketidakpuasan citra } \\
\text { tubuh" }\end{array}$} & \multirow{2}{*}{$\begin{array}{c}\text { OR } \\
95 \% \mathrm{Cl}\end{array}$} & \multirow[t]{2}{*}{$p$} & \multirow{2}{*}{$\begin{array}{l}\text { OR MH } \\
95 \% \mathrm{Cl}\end{array}$} \\
\hline & & Tidak puas & Puas & & & \\
\hline \multirow[t]{2}{*}{ Lakj-laki } & Obes & $51(39 \%)$ & $8(13 \%)$ & 13,4 & $<0,001^{*}$ & \\
\hline & Tidak obes & $19(15 \%)$ & $40,65 \%)$ & $(5,3-33,8)$ & & \\
\hline \multirow[t]{3}{*}{ Perempuan } & Obes & $36(28 \%)$ & $1(1 \%)$ & 19,5 & $0,001^{*}$ & 14,64 \\
\hline & Tidak obes & $24(18 \%)$ & $13(21 \%)$ & $(2,4-15,9)$ & & $(6,2-34,4)$ \\
\hline & Jumlah & $130(100 \%)$ & $62(100 \%)$ & & & \\
\hline
\end{tabular}

Keterangan: * $=$ Signifikan $(p<0,05)$

a Status ketidakpuasan citra tubuh, dibagi dua berdasarkan mean skor BSQ : puas: skor $\mathrm{BSQ}<62$; tidak puas: skor $\mathrm{BSQ} \geq 62$

TABEL 5. Hubungan status ketidakpuasan citra tubuh dengan aktivitas berat

\begin{tabular}{llllll}
\hline \multirow{2}{*}{$\begin{array}{c}\text { Status ketidakpuasan } \\
\text { citra tubuh" }\end{array}$} & \multicolumn{2}{c}{ Aktivitas berat } & OR & $95 \% \mathrm{Cl}$ & $p$ \\
\cline { 2 - 3 } & $\geq 0,5 \mathrm{Jam} /$ hari & $<0,5$ jam/hari & & & \\
\hline Tidak puas & $37(52 \%)$ & $93(77 \%)$ & 0,33 & $0,2-0,6$ & $<0,001^{*}$ \\
Puas & $34(48 \%)$ & $28(23 \%)$ & & & \\
\hline
\end{tabular}

Keterangan: $\quad *$ Signifikan $(p<0,05)$

a Status ketidakpuasan citra tubuh, dibagi dua berdasarkan mean skor BSQ: puas: skor BSQ $<62$; tidak puas: skor $B S Q \geq 62$

Christofer et al (16) dari penelitiannya pada siswa SMU di Yogyakarta menyatakan ada perbedaan yang bermakna mengenai persepsi citra tubuh pada siswa laki-laki dan siswa perempuan. Matz (7) menyatakan ada hubungan yang signifikan antara citra tubuh mempunyai peluang 0,33 kali untuk melakukan aktivitas berat lebih sama dengan 0,5 jam per hari (Tabel 5). Duncan et al (17) dari penelitiannya pada anak sekolah usia 11-14 tahun, menyatakan tidak ada hubungan yang signifikan antara citra tubuh dan aktivitas fisik. 
Ketidakpuasan remaja terhadap tubuhnya ternyata tidak membuat remaja meningkatkan aktivitas beratnya. Ekulend et al(18) dari hasil penelitiannya menyatakan anak dan remaja obes punya aktivitas fisik yang lebih rendah daripada kelompok kontrol, berdasarkan pada keseluruhan aktivitas dan berdasarkan waktu yang dipakai pada aktivitas fisik dalam intensitas sedang dan lebih tinggi.

Perhatian tentang berat badan dan ketidakpuasan terhadap bentuk tubuh biasanya berhubungan dengan keinginan untuk merubah penampilan dengan cara membatasi pemasukan makanan dan teknik-teknik diet lainnya. Dari penelitian ini diketahui tidak ada perbedaan yang bermakna dalam asupan energi antara remaja yang tidak puas dan puas dengan bentuk tubuhnya. Artinya remaja yang tidak puas dengan bentuk tubuhnya tidak melakukan usaha mengurangi makanan atau diet, tetapi malah mempunyai kecenderungan yang lebih besar untuk mengkonsumsi makanan yang lebih banyak (74\% remaja yang tidak puas asupan energinya lebih besar sama dengan 2200 kalori per hari).

Johnsen et al(19)menyatakan efek kombinasi diet tinggi kalori dan lemak, meningkatnya kebiasaan sedentary dan kepuasan citra tubuh dilaporkan meningkatkan jumlah obesitas pada wanita kulit hitam. Sebuah studi longitudinal yang dilakukan Foster et al (20), pada minggu ke 40 peserta rata-rata kehilangan $5,7 \pm 5,3 \%$ dari berat awal, dan berhubungan secara bermakna dengan perbaikan citra tubuh. Peningkatan kepuasan berhubungan secara bermakna dengan pemeliharaan kehilangan berat yang sangat baik selama follow up.

Dari penelitian tersebut terbukti keberhasilan menurunkan berat badan ternyata meningkatkan kepuasan atau perbaikan citra tubuh. Oleh karena itu, diperlukan inovasi untuk mencari faktor-faktor yang dapat dimodifikasi dalam hal pengawasan berat badan, yakni faktor-faktor makanan dan pola-pola aktivitas fisik. Perlu diperhatikan usaha untuk menahan pemasukan energi dan meningkatkan pemakaian energi, rancangan diet dan program olahraga serta pengembangan strategi yang mengurangi tingkat kegagalan dan menambah motivasi untuk berhasil.

\section{KESIMPULAN DAN SARAN}

Remaja obes lebih tidak puas dengan citra tubuhnya daripada remaja tidak obes. Remaja perempuan obes lebih tidak puas terhadap citra tubuhnya dibandingkan remaja laki-laki obes. Ada hubungan yang terbalik antara status ketidakpuasan citra tubuh dengan aktivitas berat. Remaja obes yang tidak puas mempunyai aktivitas berat yang lebih sedikit daripada remaja yang puas. Tidak ada hubungan yang bermakna antara status ketidakpuasan citra tubuh dengan asupan energi.

Berdasarkan kesimpulan tersebut maka disarankan, untuk menambah pengetahuan pada remaja dan orangtuanya tentang pola makan yang baik yaitu pemilihan jenis dan jumlah makanan yang sesuai dengan usia dan pertumbuhan. Remaja obes yang tidak puas dengan tubuhnya perlu diberi motivasi untuk menurunkan berat badan dengan cara mengurangi jumlah makanan yang biasa dimakan sehari-hari. Melakukan aktivitas fisik harian seperti jalan kaki ke sekolah, bersepeda, naik tangga dan mengurangi menonton TV atau kegiatan-kegiatan sedentian lainnya. Motivasi tersebut sebaiknya diberikan terus menerus oleh orangtua, guru, teman-teman sebaya.

\section{Ucapan Terima Kasih}

Penelitian ini terlaksana atas bantuan serta dukungan berbagai pihak. Peneliti mengucapkan terima kasih kepada Kepala SLTP di Kota Yogyakarta dan Kabupaten Bantul serta teman-teman peneliti pada Penelitian Bersama Obesitas pada Remaja Tahun 2003. Juga pada teman-teman yang membantu pengumpulan data dan siswa-siswi SLTP yang bersedia menjadi subjek penelitian serta semua pihak yang telah membantu terlaksananya penelitian ini.

\section{RUJUKAN}

1. Gill TP. The Global Epidemic of Obesity. Am J Clin Nutr 1999;8:75-81.

2. Sjarif DR. Child Hood Obesity, Evaluation and Management. Dalam: Soebagijo A, Sri M, Askardar T, Hendromartono, Ari S, Agung P, editors. Naskah Lengkap National Obesity Symposium II: 2003; Surabaya. Perkeni, DNC. p. 123-39.

3. Khor GL, Azmi M, Yusof, Siong TE, Mirnalini K, Mary SLH. Prevalence of Overweight among Malaysian Adults from Rural Communities. Asia Pacific J Clin Nutr 1999;8:272-9.

4. Sjarif DR. Obesity in Child Hood, Pathogenesis and Management. Dalam: Tjokroprawiro A, Hendromartono, Ari S, Hans T, Agung P, Sri M,editors. Naskah Lengkap National Obesity Symposium I: 20-21 Juli 2002; Surabaya. Perkeni, DNC. p. 155-70.

5. Adiningsih Sri. Ukuran Pertumbuhan dan Status Gizi Remaja Awal. Dalam: Dala S, Abas BJ, Iman 
S, Gustina S, Rochamah, Budi H, editors. Prosiding Kongres Nasional Persagi dan Temu IImiah XII; Jakarta, Indonesia. 2002. h. 94-110.

6. Mahdiah. Prevalensi Obesitas dan Hubungan Konsumsi Fast Food dengan Kejadian Obesitas pada Remaja SLTP Kota dan Desa di Daerah Istimewa Yogyakarta [tesis]. Yogyakarta: Universitas Gadjah Mada; 2004.

7. Matz PE, Myles SF, Gary DF, Thomas AW. Correlates of Body Image Dissatisfaction among Overweight Women Seeking Weight Loss. J Consult Clin Psychol 2002;70:1040-4.

8. Adolescents and Body Image: What's Typical and What's Not. March/April 2002. Copy Editor; $6: 1-$ 4.

9. Nichter M. Fat Talk, What Girls and Their Parents Say about Dieting. Harvard University Press; 2000. p. 1-14.

10. Huryati E. Aktifitas Fisik pada Remaja SLTP Kota Yogyakarta dan Kabupaten Bantul serta Hubungannya dengan Kejadian Obesitas [tesis]. Yogyakarta: Universitas Gajah Mada; 2004.

11. Kuczmarski RJ, Ogden CL, Guo SS, et al. 2000 CDC Growth Charts for the United States Methods and Development National Center for Health Statistic. Vital Health Stat 2002;11(246).

12. Cooper PJ, Taylor MJ, Cooper Z, Fairburn CG. The Development and Validation of the Body Shape Questionnaire. Int J Eat Disord 1996;6:485-94.

13. Williamson DA, LG Womble, NLZucker, DL Reas, MA White, DC Blouin, et al. Body Image of Assesment for Obesity (BIA-O): Development of a New Procedure. Int J Obes 2000;24:1326-32.
14. Snooks MK, Sharon KH. Relatonship of Body Size, Body Image and Self Esteem in African American, European American, and Mexican American Middle Class Women. Health Care for Women International 2002;23:460-6.

15. Metcalf PA, Scragg RKR, Willoughby P, Finau S, Tipene L. Ethnic Differences in Perceptions of Body Size in Middle-aged European, Maori, and Pasicific People Living in New Zealand. Int J Obes 2000;24:593-9.

16. Christofer MS, Hamam $\mathrm{H}$, Nawi Ng. Persepsi Siswa SMU terhadap imej Tubuh di Propinsi Daerah Istimewa Yogyakarta. In press 2004.

17. Duncan MJ, Alan N, Marc VJ. Body Image and Physical Activity in British Secondary School Children. European Physical Education 2004; Review 10:243-60.

18. Ekulend U, Jan A, Agneta Y, Cecilia R, Klaas W, Michael S. Physical Activity but not Energy Expenditure is Reduced in Obese Adolescents: a Case Control Study. Am J Clin Nutr 2002;76:93541.

19. Johnsen LAP, Marian LF, Zoran M, Melinda RS, Alan RD, Linda VH. Ethnic Differences in Correlates of Obesity between Latin-american and Black Women. Obes Res 2004;12:652-60.

20. Foster GD, Suzanne P, Thomas AW, Debra G, Jenna E, Elizabeth D. Promoting more Modest Weight Losses: a Pilot Study. Obes Res 2004;2:1271-7. 